\title{
Assessment of Nurses Knowledge and Practices Regarding The Use of Evidence-based for Pregnant Women with Pre-eclampsia
}

\author{
Doaa EL sebaey soliman', Samia Abd El hakeem Hasneen ${ }^{2}$, Somaya Ouda AbdElmoniem ${ }^{3}$ \\ and Fatma Kamal $\mathrm{Ali}^{4}$ \\ (1)Nurse Specialist in Sadr Shebein EL- kom, (2) Professor.of Obstetrics \& Woman's Health \\ Nursing- Faculty of Nursing - Benha University, (3) Assisstant professor.of Obstetrics \& Woman's \\ Health Nursing- Faculty of Nursing - Benha University and (4) Lecturer of Obstetric \& woman's \\ Health Nursing- Faculty of Nursing - Benha University
}

\section{Abstract}

Background: Once preeclampsia is diagnosed, evidence-based interventions may reduce the risk or severity of maternal and infant health outcomes of preeclampsia. Aim of the study: Was to assess nurses knowledge and practices regarding the use of evidence-based for pregnant women with pre-eclampsia. Design: A descriptive study design was utilized to achieve the aim of the study. Setting: The present study was conducted at obstetrical and gynecological department at Benha University Hospital. Sampling: A convenient sample. Tools: Three tools were used for data collection: A self-administered questionnaire, Observational checklist and Modified Likert scale. Result: There were more than one third of studied nurses $(41.7 \%)$ had average level of total knowledge about EBP and preeclampsia, less than two third of studied nurses (65\%) had satisfactory level of total practices regarding preeclampsia and more than half of studied nurses (53.4) had high level of awareness about barriers. Conclusion: There was statistical significance positive correlation between total practices, total knowledge about evidence based practices and total knowledge of preeclampsia. Recommendation: Improving nurse's awareness regarding EBP through involving them in educational programs to encourage them to utilized EBP into patient daily care.

Key words: preeclampsia, evidence-based practices, nurses.

\section{Introduction}

Evidence Based Practice (EBP) is an approach that enables nurses to provide the highest quality care based on the available best evidence, which in turn positively affects the outcome of nursing interventions to improve patient outcomes currently and in the future. It is important that an evidence-based approach of nursing care be incorporated into clinical practice settings. Thus, it is necessary to prepare nurses with competencies and key concepts of EBP (Bianchi, et al., 2018).

Evidence-based practice is the process of collecting, processing, and implementing research findings to improve clinical practice, the work environment, or patient outcomes. According to the American Nurses Association, nursing interventions should be practical, methodical decisions based on EBP research studies. Utilizing the EBP approach to nursing practice helps us provide the highest quality and most cost-efficient patient care possible (Indra, 2019).

Two factors have created the urgency for nursing to be engaged in EBP. The first is the priority place of EBP in current health policy in the advanced countries as a mean of delivery of effective and sufficient health 
care. Another factor is that other health professions are becoming more accomplished at using evidence in their decision making. If nurses do not get involved in EBP, they will find themselves increasingly isolated and powerless (Abdel-Aziez, et al., 2016).

Pre-eclampsia is considered as one of the most common medical complications during pregnancy. Preeclampsia is diagnosed with systolic blood pressure $\geq 140$ or diastole $\geq 90$, presence of proteinuria with or without edema. Pre-eclampsia occurs after 20 weeks of pregnancy, affects about $5 \%$ to $8 \%$ of all pregnancies, when $\mathrm{PE}$ is accompanied with seizure, is called eclampsia. The prevalence of preeclampsia in developing countries has been reported to be $1.8 \%-16.8 \%$. According to WHO, $2.3 \%$ of all cases of preeclampsia lead to eclampsia and most of the deaths associated with preeclampsia were due to delayed diagnosis, improper management and nursing care program (Tabatabaeian et al., 2018).

Complications of eclampsia include cardiovascular disease, renal disease, cerebrovascular disease and shorten life expectancy. Additionally, adverse fetal effects from PEE include intrauterine growth restriction, small for gestational age, respiratory distress syndrome, transient tachypnea of the newborn, anemia, apnea, asphyxia, perior intraventricular haemorrhage, cardiomyopathy, cerebral palsy and persistent pulmonary hypertension of the newborn. Furthermore, preeclampsia and eclampsia are leading causes of perinatal mortality (Thilaganathan, and Kalafat, 2019).

Early detection, rapid response, accurate management and timely delivery of women with preeclampsia with severe features and eclampsia reduces maternal and fetal complications and deaths. Nurses' knowledge and skills about diagnosis and management of these conditions is critical factor in maternal and neonatal morbidity and mortality (Angelina, et al., 2020).

Nurses are the largest group of health care providers and have a key role in ensuring the promotion of health care and delivering better services. EBP is important to the professional development responsibility and capabilities of nurses and it has become an important subject in nursing and has integrated into daily practice. In addition, nurses who have based their practices on scientific evidence provide their clients and organization better and more cost-effective nursing care than those who do not base their practice on EBP ( Ellboudy, et al., 2018).

\section{Significant of the study:}

Because preeclampsia affects $2-8 \%$ of pregnancies and contributes to higher levels of maternal and infant morbidity and mortality (Tabatabaeian, et al., 2018), it is considered a significant health concern. In a study conducted to estimate the prevalence of hypertensive diseases of pregnancy in Egypt, (4.2\%) had pregnancy induced hypertension, (3.8\%) had preeclampsia and eclampsia (Gabal et al., 2017).

Evidence-based practice is a crucial tool for delivering high-quality care in numerous nursing specialties. Evidence-based practice enables nurses to make data-backed solutions that incorporate clinical expertise and current research into the decision-making process (Wu, et al., 2018).

Aim of the study:

The aim of the present study was to assess the application of evidence based practice for pregnant women with preeclampsia.

The aim was achieved through the following:

1. Assess nurses' knowledge about evidence based nursing practices for preeclampsia. 
2. Assess nurses' practices about evidence based nursing practices for preeclampsia.

3. Studying barriers for using evidence based nursing practices.

\section{Subjects and method}

\section{A-Research designs:}

A descriptive research designs was utilized to achieve the aim of the study.

\section{B- Setting:}

The present study was conducted in obstetrical and gynecological department at Benha University Hospital.

\section{C- Sampling:}

Sample type: A convenient sample was selected.

Sample size: All nurses (60 nurses) who were working at obstetrical and gynecological department at Benha University Hospital.

\section{Tools of data collection:}

Three tools were used for data collection prepared by the researcher.

\section{Tool I: A self-administered questionnaire:}

It was developed by the researcher under supervision of experts through relevant review of literature (Verloo, et al., 2017; Nwanodi, 2016). It was written in simple clear Arabic language and it consisted of the following two parts:

Part1: General characteristics of studied sample such as (age, level of education ,experience years and received training programs about the utilization of evidence based practice for caring pregnant women with preeclampsia).

Part 2: Assessment of studied nurse's knowledge regarding evidence based applying for preeclampsia cases through item was written in simple Arabic language and in the form of multiple choice questions for assessing the nurses' knowledge through the following sections:

- Section (1) knowledge regarding evidence based that apply for preeclampsia, it consist of (6) items (definition of EBP, steps of EBP, important of EBP, EBP for caring women with preeclampsia, EBP that given for women with preeclampsia and EBP to protect women from preeclampsia).

- $\quad$ Section (2) general knowledge about preeclampsia, it consist of (9) items (definition of preeclampsia, degree of preeclampsia, risk factor of preeclampsia, signs and symptoms of preeclampsia, danger signs for women with preeclampsia, complication of preeclampsia, tests that confirm preeclampsia, times of visits' women with preeclampsia and medications that given for women with preeclampsia.

- $\quad$ Section (3) knowledge about HELLP syndrome, it consist of (3) items (definition of HELLP syndrome, signs and symptoms of HELLP syndrome and management for HELLP syndrome.

- Section (4) knowledge about magnesium sulfate, it consist of (9) items (the loading dose of magnesium sulfate, maintenance dose of magnesium sulfate, precautions to be followed while giving magnesium sulfate, the most common side effect of magnesium sulfate, symptoms of magnesium sulfate toxicity, the antagonist used in case of magnesium sulfate toxicity, respiratory depression is a concern when blood levels of magnesium sulfate reach, the most common cause of accidents of magnesium sulfate and the doctor should be 
informed if the woman receiving magnesium sulfate is suffering from.

\section{Scoring system:}

Each item was assigned a score of (2) given when the answer was completely correct, a score (1) was given when the answer was incompletely correct and a score (0) was given when the answer was don't know. The total score of each section was calculated by summation of the scores of its items. The total score for the knowledge of nurses was calculated by the addition of the total score of all section.

The score of total knowledge was classified as the follows:

- $\quad$ Good : $(>75 \%)$

- Average: $(60-<75 \%)$.

- Poor: $(<60 \%)$.

\section{TOOL II. Observational checklist:}

It was used to assess evidence based nursing practice regarding management of preeclampsia. Each statement scored as follow: (1) if done and (0) if not done. The score of total practices was classified as the follows:

- Satisfactory level: $\geq 60 \%$

- Unsatisfactory: $<60 \%$

\section{TOOL III. Modified Likert scale:}

This scale was adapted from (JensenDoss, and Hawley, 2010) and modified by the researcher to measure studied nurse's barrier affecting EBP utilization. The researcher used a simple Arabic language to suit the level nurses' understanding. This scale consist of (10) items (Lack of nurses and medical team regarding number of cases, Lack of capabilities and tools in hospital, not attending the training courses, little information is available on EBP, lack of technology in the field of nursing, sources of access to evidence-based practices are limited, inability of nurses to read and analyze evidence-based research, nursing resistance to change, insufficient support for nurses, Lack of time) with (3) points ( agree, uncertain, disagree).

\section{Scoring system:}

Each items scored as (2) if awareness was agreed, (1) if it was uncertain and (0) if it was disagree. The score of total awareness about barriers:

High: ( $>75 \%)$

Moderate: $(60-75 \%)$.

Low: $(<60 \%)$

Validity of the tools:

Tools of data collection were reviewed by panel expertise (three specialized university professionals in the field of obstetrics and gynecology). Minor modification was done based on jury opinion.

\section{Reliability of tools:}

It was measured by using cronbachs' Alpha that indicated that reliability for knowledge was 0.71 , reliability for practices was 0.83 and reliability for barriers was 0.68 .

\section{Ethical consideration:}

- The aim of the study was explained to each nurse before applying the tools to gain their confidence and trust.

- Ethical aspect was considered before starting the study that includes the following:

- The research approval was obtained from Scientific Research Ethical Committee, Faculty of Nursing at Benha University before starting the study. 
- An oral consent was obtained from each nurse to participate in the study and withdraw when she needs without obligation.

- The study has no physical, social, or psychological risk on the Participants, the data were collected and treated confidentially.

\section{Pilot study:}

A pilot study was conducted on $10 \%$ of the total sample size (6) nurses before starting data collection to test the clarity, arrangement of the items, feasibility and applicability of the tools as well as to estimate the needed time to fill questions and to make sure that items are understood. No modifications were done and the nurses in the pilot study were included from the main study sample.

\section{Field work:}

The current study started from the beginning of June 2020 to the end of August 2020. The researcher visited the pre mentioned setting 3 days per week (Sunday, Tuesday and Thursday) from 9.00 Am to 2.00 $\mathrm{Pm}$. This phase encompassed interviewing each nurse a separate place to maintain the confidentiality of the study. At the beginning of the interview the researchers greeted the nurses, introduced themselves to each nurse included in the study, explained the purpose of the study, provided the nurse with all information about the study and take oral consent to participate in the study.

Nurses were interviewed according to sequent of signature name in hospital registration book, using a self-administered questionnaire sheets (Tool I), to assess general characteristics of studied sample and women`s knowledge regarding evidence based applying for preeclampsia cases. The researcher utilized the observational check list
(Tool II) to assess nurse's practices regarding management of preeclampsia. Finally: the researcher utilized modified Likert scale (Tool III) to each participant to assess barriers affecting EBP utilization.

Average time for the completion of each nurse interview was around (30-45 minutes). A number of interviewed nurse / day ranged from 3-4 women.

\section{Statistical analysis:}

Data were verified prior to computerized entry. The Statistical Package for Social science (SPSS version 20.0) was used. Descriptive statistics were applied in the form of mean and standard deviation for quantitative variables. Qualitative categorical variables were compared using chi-square test. Pearson correlation coefficient was calculated to estimate the closeness association between variables. The p-value is the degree of significant and using the correlation (r) test. The p-value is the probability that an observed difference is due to chance and not a true difference. A significant level value was considered when p-value $<0.05$ and a highly significant level value was considered when $\mathrm{p}$-value $<0.001$ while $\mathrm{p}$-value $>0.05$ indicates non significant results.

\section{Study limitations:}

Many nurses were busy most of the time in daily work during data collection.

\section{Results}

Table (1): shows that more than half of studied nurses $(56.7 \%)$ were in age group 20-30 years old with a mean age of $32.45 \pm 9.68$ years. Regarding to educational level, less than two third of studied nurses $(61.7 \%)$ had technical institute. In addition more than one third of studied 
nurses $(41.7 \%)$ had more than ten years of experience. Concerning to training courses, more than half of studied nurses $(53.3 \%)$ hadn't attended training courses and from this nurses less than two third (59.4\%) hadn't attend courses in their field of work. Most of studied nurses $(88.3 \%)$ were married. Regarding to application of EBP more than three quarters $(76.7 \%)$ of studied nurses didn't agree that EBP could be applied easily in the field of nursing care

Table( 2) indicates that less than two third of studied nurses(61.7) had incomplete correct answer regarding definition of EBP. About half of studied nurses(50,0\%) had incomplete correct answer regarding steps of EBP and about half of studied nurses (50\%) had don't know answer about importance of EBP application while more than half of studied nurses (51.7\% and 53.3\%) had incomplete correct answer regarding EBP for caring women with preeclampsia and EBP that given for women with preeclampsia respectively. In addition about two third $(65.0 \%)$ of them had complete correct answer regarding EBP to protect women from preeclampsia.

Table (3) illustrates that more than two third of studied nurses $(68.3 \%)$ had complete correct answer regarding definition and complication of preeclampsia. About three quarters $(75 \%)$ of studied nurses had complete correct answer regarding signs and symptoms of preeclampsia and Diagnosis of preeclampsia . Less than two third $(60.0 \%$ and $63.3 \%$ ) had incomplete correct answer regarding degree and risk factor of preeclampsia respectively. while more than two third of studied nurses $(71.7 \%)$ had complete correct answer regarding danger signs for women with preeclampsia. In addition more than two third of studied nurses $(68.3 \%$ and $73.3 \%)$ had incomplete correct answer regarding Frequency of visits for women with preeclampsia and medication that given for women with preeclampsia respectively.

Figure (1) shows that more than one third of studied nurses $(41.7 \%)$ had average level of total knowledge about EBP and preeclampsia..

Table (4) shows that mean and stander deviation of Practical skills during management of preeclampsia is $10.70 \pm 2.776$, while for Skill of blood pressure measurement is $13.07 \pm 2.991$ and for total practices is $52.66 \pm 5.52$.

Figure (2) shows that less than two third of studied nurses $(65 \%)$ had satisfactory level of total practices regarding preeclampsia.

Figure (3) shows that more than half of studied nurses (53.4) had high level of awareness about barriers.

Table (5) illustrate that there were positive correlation between total knowledge and total practices while there were negative correlation between total practices and total barrier.

Table (6) shows that there were statistically significant relation between total knowledge level and total practices $(\mathrm{p}<0.05)$.

Table (7) shows that there were statistical significance positive correlation between total practices, total knowledge about evidence based practices and total knowledge of preeclampsia.

Table (8) shows that there were statistical significance positive correlation between total knowledge about evidence based practices and total knowledge about preeclampsia. 
Table (1): frequency distribution of studied nurses regarding their socio-demographic characteristics $(\mathbf{n}=\mathbf{6 0})$.

\begin{tabular}{|c|c|c|}
\hline Socio-demographic characteristic & No & Percent \\
\hline \multicolumn{3}{|l|}{ 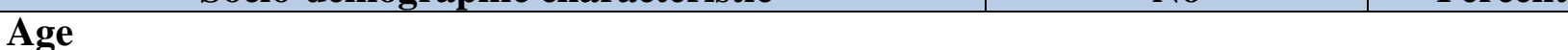 } \\
\hline$<20-30$ & 34 & 56.7 \\
\hline$>30$ & 26 & 43.3 \\
\hline Mean \pm SD & $32.45 \pm 9.68$ & \\
\hline \multicolumn{3}{|l|}{ Education level } \\
\hline Diploma & 19 & 31.7 \\
\hline technical Institute & 37 & 61.7 \\
\hline Bachelor & 4 & 6.7 \\
\hline \multicolumn{3}{|l|}{ Years of experience } \\
\hline$<5$ & 17 & 28.3 \\
\hline $5-10$ & 18 & 30.0 \\
\hline$>10$ & 25 & 41.7 \\
\hline \multicolumn{3}{|l|}{ Training courses } \\
\hline Yes & 28 & 46.7 \\
\hline No & 32 & 53.3 \\
\hline \multicolumn{3}{|l|}{ If yes $(n=28)$. In your filed of work } \\
\hline Yes & 19 & 59.4 \\
\hline No & 13 & 40.6 \\
\hline \multicolumn{3}{|l|}{ Marital status } \\
\hline Single & 4 & 6.7 \\
\hline Married & 53 & 88.3 \\
\hline Divorced & 3 & 5.0 \\
\hline \multicolumn{3}{|l|}{ Number of nurses in shift } \\
\hline$<3$ & 24 & 40.0 \\
\hline$>3$ & 36 & 60.0 \\
\hline \multicolumn{3}{|c|}{ EBNP could be applied easily in the field of nursing care } \\
\hline Yes & 14 & 23.3 \\
\hline No & 46 & 76.7 \\
\hline
\end{tabular}

Table (2): frequency distribution of studied nurses regarding their knowledge about evidence based practice (EBP)

\begin{tabular}{|c|c|c|c|c|c|c|}
\hline \multirow[t]{2}{*}{ Knowledge items } & \multicolumn{2}{|c|}{$\begin{array}{l}\text { Complete } \\
\text { Correct }\end{array}$} & \multicolumn{2}{|c|}{ incomplete Correct } & \multicolumn{2}{|c|}{ I don't know } \\
\hline & $\mathrm{No}$ & $\%$ & No & $\%$ & No & $\%$ \\
\hline Definition of EBP & 2 & 3.3 & 37 & 61.7 & 21 & 35.0 \\
\hline Steps of EBP & 2 & 3.3 & 30 & 50.0 & 28 & 46.7 \\
\hline Importance of EBP application & 1 & 1.7 & 29 & 48.3 & 30 & 50.0 \\
\hline $\begin{array}{l}\text { EBP for caring women with } \\
\text { preeclampsia }\end{array}$ & 25 & 41.7 & 31 & 51.7 & 4 & 6.7 \\
\hline $\begin{array}{l}\text { EBP that given for women with } \\
\text { preeclampsia }\end{array}$ & 28 & 46.7 & 32 & 53.3 & 0 & 0.0 \\
\hline $\begin{array}{l}\text { EBP to protect women from } \\
\text { preeclampsia }\end{array}$ & 39 & 65.0 & 21 & 35.0 & 0 & 0.0 \\
\hline
\end{tabular}


Table (3): frequency distribution of studied nurses regarding their knowledge about preeclampsia $(\mathbf{n}=60)$.

\begin{tabular}{|l|l|l|l|l|l|l|}
\hline \multirow{2}{*}{ Knowledge items } & \multicolumn{2}{l}{ Complete Correct } & \multicolumn{2}{l|}{ Incomplete Correct } & \multicolumn{2}{l|}{ I don't know } \\
\cline { 2 - 8 } & No & $\%$ & No & $\%$ & No & $\%$ \\
\hline Definition of preeclampsia & 41 & 68.3 & 19 & 31.7 & 0 & 0.0 \\
\hline Degree of preeclampsia & 18 & 30.0 & 36 & 60.0 & 6 & 10.0 \\
\hline Risk factor of preeclampsia & 22 & 36.7 & 38 & 63.3 & 0 & 0.0 \\
\hline $\begin{array}{l}\text { signs and symptoms of } \\
\text { preeclampsia }\end{array}$ & 45 & 75.0 & 15 & 25.0 & 0 & 0.0 \\
\hline $\begin{array}{l}\text { Danger signs for women with } \\
\text { preeclampsia }\end{array}$ & 43 & 71.7 & 17 & 28.3 & 0 & 0.0 \\
\hline Complication of preeclampsia & 41 & 68.3 & 19 & 31.7 & 0 & 0.0 \\
\hline Diagnosis of preeclampsia & 45 & 75.0 & 15 & 25.0 & 0 & 0.0 \\
\hline $\begin{array}{l}\text { Frequency of visits for women } \\
\text { with preeclampsia }\end{array}$ & 18 & 30.0 & 41 & 68.3 & 1 & 1.7 \\
\hline $\begin{array}{l}\text { Medication that given for women } \\
\text { with preeclampsia }\end{array}$ & 16 & 26.7 & 44 & 73.3 & 0 & 0.0 \\
\hline
\end{tabular}

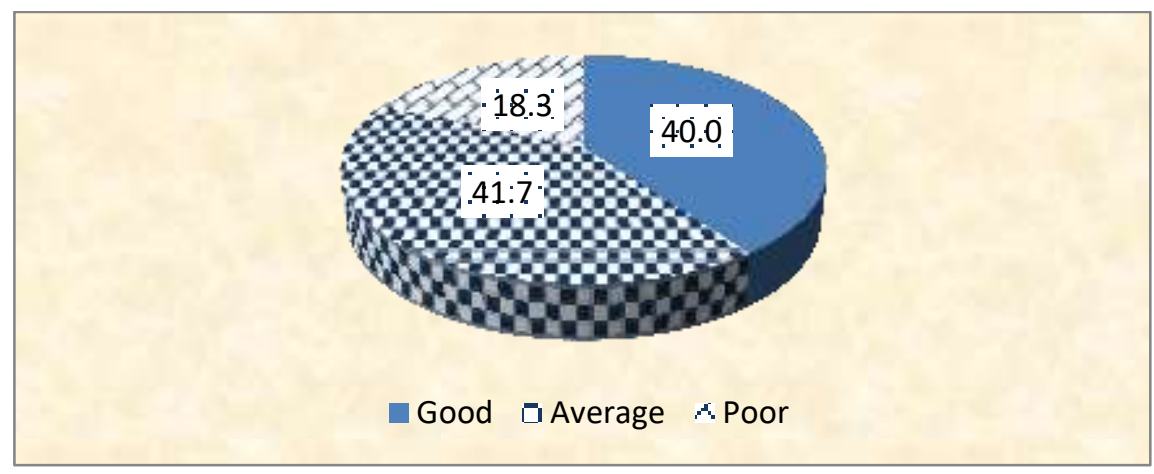

Figure (1): percentage distribution of studied nurses regarding their total knowledge level $(\mathbf{n}=60)$.

Table (4): mean and stander deviation of total practices score regarding preeclampsia procedure among studied nurses

\begin{tabular}{|l|l|l|l|l|}
\hline Total practices items & Min & Max & Mean & ISD \\
\hline Practical skills during management of preeclampsia & 5 & 16 & 10.70 & \pm 2.776 \\
\hline Admission procedure & 1 & 3 & 2.47 & \pm 0.791 \\
\hline Infection control standard & 4 & 8 & 5.92 & \pm 1.369 \\
\hline Skill of blood pressure measurement & 8 & 17 & 13.07 & 2.991 \\
\hline Practical skill of giving magnesium sulfate & 3 & 7 & 4.75 & \pm 1.271 \\
\hline $\begin{array}{l}\text { Assess deep tendon reflex during magnesium sulfate } \\
\text { therapy }\end{array}$ & 1 & 1 & 1.00 & \pm 0.00 \\
\hline Assess pitting edema & 4 & 9 & 6.66 & \pm 1.853 \\
\hline Practical skill of weighing the women & 2 & 5 & 4.22 & \pm 0.852 \\
\hline Test protein urine & 3 & 6 & 5.05 & \pm 0.990 \\
\hline Total & 40 & 64 & 52.66 & \pm 5.52 \\
\hline
\end{tabular}




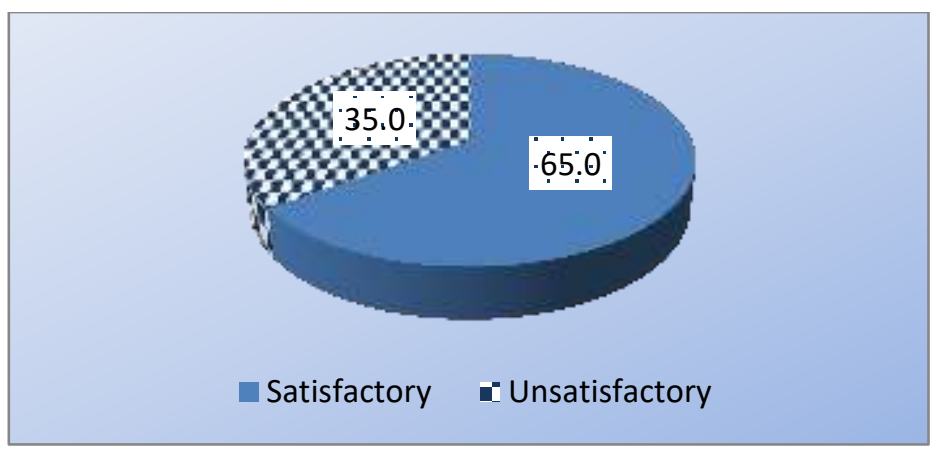

Figure (2) percentage distribution of studied nurses regarding their total practices level $(n=60)$.

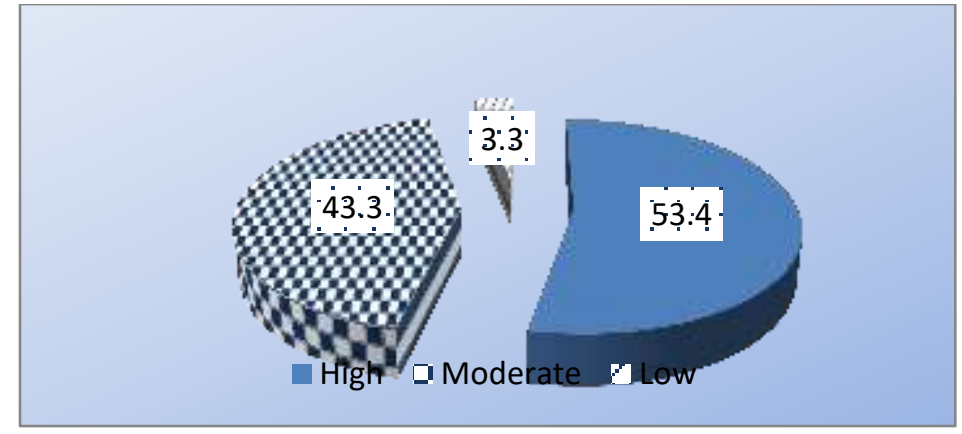

Figure (3): percentage distribution of studied nurses regarding their total awareness about barriers level $(\mathbf{n}=60)$.

Table (5): correlation matrix between total knowledge, practices and barriers

\begin{tabular}{|l|l|l|l|l|}
\hline \multicolumn{2}{|c|}{ variables } & total knowledge & total practices & total barrier \\
\hline total knowledge & $\mathrm{R}$ & & & \\
\hline & $\mathrm{p}$-value & & .128 & .036 \\
\hline total practices & $\mathrm{R}$ & .128 & .328 & .786 \\
\hline & $\mathrm{p}$-value & .328 & & $-.038-$ \\
\hline total barrier & $\mathrm{R}$ & .036 & & .775 \\
\hline & $\mathrm{p}$-value & .786 & $-.038-$ & \\
\hline
\end{tabular}

Table (6) Relation between total knowledge level and total practices level among studied nurses

\begin{tabular}{|c|c|c|c|c|c|c|}
\hline $\begin{array}{r}\text { Level of } \\
\text { practices }\end{array}$ & Unsatisfactory & $=21)$ & Satisfactory $\quad(\mathbf{I}$ & $=39)$ & $\mathbf{X}^{2}$ & p-value \\
\hline $\begin{array}{l}\text { Level of } \\
\text { knowledge }\end{array}$ & No & $\%$ & No & $\%$ & & \\
\hline Poor $(n=11)$ & 11 & 52.4 & 0 & 0 & 6.307 & $0.043 *$ \\
\hline $\begin{array}{l}\text { Average } \\
(\mathrm{n}=\mathbf{2 5})\end{array}$ & 6 & 28.6 & 19 & 48.7 & & \\
\hline Good $(n=24)$ & 4 & 19.0 & 20 & 51.3 & & \\
\hline
\end{tabular}


Table (7) correlation between total practices, total knowledge about evidence based practices and total knowledge of preeclampsia

\begin{tabular}{|l|l|l|}
\hline \multicolumn{1}{|c|}{ Variables } & \multicolumn{2}{c|}{ Total practices } \\
\cline { 2 - 3 } & $\mathrm{R}$ & $0.003^{*}$ \\
\hline $\begin{array}{l}\text { Total knowledge about } \\
\text { preeclampsia }\end{array}$ & 0.571 & $0.005^{*}$ \\
\hline $\begin{array}{l}\text { Total knowledge about } \\
\text { evidence based practices }\end{array}$ & 0.482 & \\
\hline
\end{tabular}

Table (8) correlation between total knowledge about evidence based practices and total knowledge about preeclampsia

\begin{tabular}{|l|l|l|}
\hline \multirow{2}{*}{ Variables } & \multicolumn{2}{|l|}{ Total knowledge about evidence based practices } \\
\cline { 2 - 3 } & $\mathrm{R}$ & $\mathrm{p}$-value \\
\hline $\begin{array}{l}\text { Total knowledge about } \\
\text { preeclampsia }\end{array}$ & 0.375 & $0.003^{*}$ \\
\hline
\end{tabular}

\section{Discussion}

Evidence based nursing practice is an approach that enables nurses to provide the highest quality care based on the available best evidence, which in turn, positively affects the outcome of nursing interventions, to improve patient outcomes currently and in the future. It is important that an evidencebased approach of nursing care be incorporated into clinical practice settings. Thus, it is necessary to prepare nurses with competencies and key concepts of EBP (Higgins, et al., 2019).

Preeclampsia remain the main threat during pregnancy until now. It is define as a multi-system disorder of pregnancy characterized by hypertension and proteinuria with or without edema after 20 weeks of gestation (serban, et al., 2018).

The current study aimed to assess the application of evidence based practice for pregnant women with preeclampsia. This aim was achieved through a descriptive study designs that answered the research questions about the level of nurses' knowledge about evidence based nursing practices for preeclampsia, the level of nurses' practice about evidence based nursing practices for preeclampsia and barriers for using evidence based nursing practices.

\section{Total knowledge regarding preeclampsia and EBP}

Concerning the studied nurses' total knowledge. The current study showed that more than one third of staff nurses had average level of total knowledge. This result agreed with (Ahmed, 2017) who study "Impact of a tailored Intensive Educational Program upon Preeclampsia on Nurses' Knowledge" and reported that only ten out of sixty had optimal knowledge. On opposite of that, (Angelina, et al., 2020) who study "Knowledge on prevention and management of preeclampsia and eclampsia among nurses in primary health settings" found that $(51.2 \%)$ had adequate knowledge about preeclampsia. For my point of view, studied nurses had average level of total knowledge due to lack of training programs about preeclampsia and EBP. 
Knowledge about evidence based practice.

The inclusion of EBP in nursing provides nurses with the scientific research to make well-founded decisions. Through EBP, nurses can stay updated about new medical protocols for patient care. By searching for documented interventions that fit the profiles of their patients, nurses can increase their patients' chances for recovery. EBP enables nurses to evaluate research so they understand the risks or effectiveness of a diagnostic test or treatments. The application of EBP enables nurses to include patients in their care plan. This allows patients to have a proactive role in their own healthcare since they can voice concerns, share their values and preferences and make suggestions on how they want to proceed (Rasmussen, et al., 2018).

The present study revealed that less than two third of staff nurses had incomplete correct answer regarding definition of EBP. This might be due to lack of preparation of nurses in undergraduate studied and in work place hospital about EBNP, So the state must pay attention to the development of education and increase the curriculum with EBP. The result of present study was congruent with (Ellboudy, et al., 2018), whose study title "Nurse Managers' Perceived Knowledge and Skills Regarding Evidence-Based Nursing Practice" and found that nurses had low knowledge about EBP.

As well as, the result of the present study were in the same harmony with (Stokke, et al., 2014) who study " Evidence based practice beliefs and implementation among nurses: a cross-sectional study" and mentioned that nurses had lack of knowledge about EBP. Seldom incorporated research findings into practice and they tended to use knowledge derived from experience and social interactions.

The results of the present study showed that, about half of staff nurses had incomplete correct answer regarding steps of EBP. The result of the present study agreed with (Enuku and Adeyemo, 2014) who study "Knowledge, beliefs and teaching strategies of evidence based practice among nurse educators/lecturers in nursing institutions in Benin City" and illustrated that about $68 \%$ of the respondents had no knowledge about the steps of EBP.

In this respect, (Hussein and Hussein, 2014) who study " Nursing educators' knowledge, skills in evidence-based practice and their critical thinking skills: self-report study" stated that the culture in health care agenesis and school of nursing in Egypt didn't encourage utilization of EBP literacy.

In contrast with findings of the present study, (Upton, et al., 2015) who study " The evidence- based practice profiles of academic and clinical staff involved in pre-registration nursing students' education " indicated that nurses had a high level of knowledge and skills of EBP especially those had training on EBP.

This study result may be justified by the fact that Egypt is one of the developing countries and access to data base is very restricted to governmental hospitals.

\section{General knowledge regarding preeclampsia.}

The present study illustrated that more than two third of staff nurses had complete correct answer regarding definition and complication of preeclampsia. These findings agreed with (Munirathnamma, et al., 2013) in the study "Knowledge of Staff Nurses Regarding Management of Pregnancy Induced Hypertension (PIH)" who found that, more than half of the studied sample had correct knowledge regarding definition of toxemia of pregnancy.

The current study revealed that about three quarters of staff nurses had complete correct answer regarding signs and symptoms 
of preeclampsia and diagnosis of preeclampsia. This result disagreed with (Stellenberg and Ngwekazi., 2016) who studied " Knowledge of midwives about hypertensive disorders during pregnancy in primary healthcare" and found that the gab in the knowledge of nurses regarding hypertensive disorders during pregnancy was identified, only fifty six percent of participant answered the questions on the clinical manifestations of preeclampsia, Whereas, twenty eight percent had no information about preeclampsia.

From my point of view, good knowledge about preeclampsia was due to increase number of cases with preeclampsia.

The present study clarified that, Less than two third of the studied sample had incomplete correct answer regarding degree and risk factor of preeclampsia. This result disagreed with (Zahran, et al., 2018) who study titled "Nurses' practical skills provided for mother With Toxemia of Pregnancy" who found that, more than two third had satisfactory knowledge about risk factor of toxemia.

More than two third of staff nurses had incomplete correct answer regarding medication that given for women with preeclampsia. The result of the present study agreed with (Lakshmamma and Munirathnamma, 2013) who study "Knowledge of staff nurses regarding management of pregnancy induced hypertension" found that the majority of them had incorrect knowledge about medication given for toxemic mother because this study subjects were from different cultural background and different educational level.

The result of the present study showed that less than two third of staff nurses had satisfactory level of total practices regarding preeclampsia. This result agreed with (Tadele, et al., 2020) who study" Assessment of knowledge and practice of nurses working in gynecology emergency room towards pregnancy induced hypertension in selected government public hospitals found in Addis Ababa, Ethiopia" and found that Among the total 78 charts reviewed, $39(50 \%)$ of the charts had showed good practice towards pregnancy induced hypertension.

The present study showed that more than two third of staff nurses had satisfactory practice regarding skill of blood pressure measurement. In addition, more than three quarters of staff nurses had satisfactory practice related to admission procedure. The results of this study agreed with (Zahran, et al., 2018) who reported that, more than three quarter of the studied nurses had satisfactory practice related to blood pressure measurement and more than three quarter 88.7 of mothers were satisfied with nurses ${ }^{\text {ee }}$ practices about greeting on admission. In addition, these findings were consistent with (Elmenshawy, et al., 2016) who investigate "Evidence Based Nursing Practices In Preeclampsia Among Pregnant Woman" found that more than half studied sample had correct score regarding measuring and recording blood pressure.

As regards test protein in urine, the present findings showed that more than three quarters of staff nurses had satisfactory practice. These findings disagreed with (Boller et al, 2003) who conduct a study about "Quality and Comparison of antenatal care in public and private providers in the United Republic of Tanzania" and reported that only one third had done proteinuria test with good level to assess and diagnosis preeclampsia. This due to this study was may be from different cultural background and different educational level.

The result of this study came in the same line with (Abdel Aziz, et al., 2014) who study 
"Effect of an Evidence Based Practice Program on Nurse's Knowledge and Practice" and found that there was no significant relation between nurses' knowledge and their general characteristics.

These findings were matched with (Zahran, et al., 2018) who approved that, there was no relation between nurses' practices and their demographic characteristics.

On the other hand this result disagreed with (Elmenshewy, et al., 2016) who found positive relation between nurses' practices and their demographic characteristics and there was highly significant statistical difference at $\mathrm{P}$ - value $<0.05$.

\section{Conclusion}

More than one third of studied nurses had average level of total knowledge regarding preeclampsia and EBP. Less than two third of studied nurses had satisfactory level of total practices regarding preeclampsia. More than half of studied nurses had high level of awareness about barriers for EBP. Moreover, there was statistically significant relation between total knowledge level and total practices. Meanwhile there was statistical significance positive correlation between total practices, total knowledge about evidence based practices and total knowledge of preeclampsia. Also, there was statistical significance positive correlation between total knowledge about evidence based practices and total knowledge about preeclampsia. The above-mentioned findings were answered the study questions.

\section{Recommendations}

- Developing continuous educational programs for nurses working in obstetrics and gynecology department to enhance their knowledge and practices regarding care with preeclampsia.
- Improving nurse's awareness regarding EBP through involving them in educational programs to encourage them to utilized EBP into patient daily care.

- Integrate the guidelines to undergraduate curriculum students' nurses to be further applied into their practice after graduation

- Disseminate the guidelines to all maternity and maternal child health care services.

\section{Further studies:}

- Further study is needed to investigate the reapplication of the present study on another setting and on large sample size.

- Further research is needed on wide scale to determine the barriers affecting utilization of EBP during provide care for toxemic pregnant women.

\section{References}

Abdel-Aziez, S., Ali, S., Metwally, F., Mohammed, W., (2016). Effect of an Evidence Based Practice Program on Nurse's Knowledge and Practice. Zagazig Nursing Journal, 12(1), 99-113.

\section{Ahmed, S. S., Helmy, H. K., \& Mohamed,} A. A. (2017). Impact of a tailored Intensive Educational Program upon Preeclampsia on Nurses 'Knowledge at Beni-Suef City, Egypt. International Journal of Nursing Science, 7(4): 79-83.

Angelina, J. A., Kibusi, S. M., Mwampagatwa, I., \& Ernest, A. (2020). Knowledge on prevention and management of preeclampsia and eclampsia among nurses in primary health settings: baseline findings from an interventional study in Dodoma Region, Tanzania. EA Health Research Journal, 4(1), 33-40

Bianchi, M., Bagnasco, A., Bressan, V., Barisone, M., Timmins, F., Rossi, S. \& 
Sasso, L. (2018). A review of the role of nurse leadership in promoting and sustaining evidence-based practice. Journal of Nursing Management, 26(8), 918-932.

Boller C, Wyss K, Mtasiwa D, et al., (2003). Quality and Comparison of antenatal care in public and private providers in the United Republic of Tanzania. Bulletin of the World Health Organisation;81:116-122

Ellboudy, D., Eid, N., \& Rashad, Z. (2018). Nurse Managers' Perceived Knowledge and Skills Regarding Evidence-Based Nursing Practice. Menoufia Nursing Journal, 3(2), 2734

Elmenshewy, S., Nahed, F., and Hassan, S., (2016). Investigate Evidence Based Nursing Practices In Preeclampsia Among Pregnant Woman. IOSR Journal of Nursing and Health Science (IOSR -JNHS), 5(2):25-32.

Enuku, C. A., and Adeyemo, F. O. (2014). Knowledge, beliefs and teaching strategies of evidencebased practice among nurse educators/lecturers in nursing institutions in Benin City, Edo State, Nigeria. International Journal of Collaborative Research on Internal Medicine \& Public Health, 6(1), 0-0.

Gabal, M. S., Abousaif, H. A., Salah-Eldin, W., and Abdelaziz, A. M., (2017). Frequency of Hypertension Associated with Pregnancy among The Pregnant Women Attending Maternal and Child Care Centers in Belbeis City. Egyptian Journal of Community Medicine. 35(3): 83.

Higgins, A., Downes, C., Varley, J., P. Doherty, C., Begley, C., \& Elliott, N. (2019). Evidence-based practice among epilepsy specialist nurses in the Republic of Ireland: Findings from the SENsE study. Journal of nursing management, 27(4), 840847.

Hussein, A. H., and Hussein, R. G. (2014). Nursing educators' knowledge, skills in evidence-based practice and their critical thinking skills: self-report study. Life Science Journal, 11(4), 231-238.

Indra, V. (2019). Evidence-based Practice in Nursing. International Journal of Nursing Education and Research, 7(2), 293-296.

Jensen-Doss, A., and Hawley, K. M. (2010). Understanding barriers to evidence-based assessment: Clinician attitudes toward standardized assessment tools. Journal of Clinical Child \& Adolescent Psychology, 39(6), 885-896.

Lakshmamma T, and Munirathnamma M., (2013). Knowledge of staff nurses regarding management of pregnancy induced hypertension (PIH). International Journal of Humanities and Social Science Invention, 2(11):8-12.

Munirathnamma, M., and Lakshmamma, T., (2013).Knowledge of staff nurses regarding management of pregnancy induced hypertension (PIH). International Journal of Humanities andSocial Science invention, 2(11): 8-12.

Nwanodi, O., (2016). Preeclampsia-eclampsia adverse outcomes reduction: The preeclampsia-eclampsia checklist. In Healthcare .4(2):26.

Rasmussen, C. D. N., Højberg, H., Bengtsen, E., \& Jørgensen, M. B. (2018). Identifying knowledge gaps between practice and research for implementation components of sustainable interventions to improve the working environment-A rapid review. Applied ergonomics, 67: 178-192.

Serban D., Crisan C., Serban C., Serbu I.B.M., Kundani N., Poroch V., Sharma A., Buciu V., Horhat L.D., Sas I., Biris M., and Ratiu A., (2018). Effects of Acetylsalicylic Acid in Preterm Preeclampsia Prevention, Revista de Chimie (Bucharest), 69 (5) : 1203.

Stellenberg EL, Ngwekazi NL., (2016). Knowledge of midwives about hypertensive disorders during pregnancy in primary 
healthcare. Afr J Prm Health Care Fam Med, $8(1): 899$.

Stokke, K., Olsen, N. R., Espehaug, B., \& Nortvedt, M. W., (2014). Evidence based practice beliefs and implementation among nurses: a cross-sectional study. BMC nursing, 13(1): 8 .

Tabatabaeian M., Kordi M., Dadgar S., Esmaeily H., and Khadivzadeh T., (2018). Comparing the effects of simulation-based training, blended, and lecture on the simulated performance of midwives in preeclampsia and eclampsia, Journal of Education and Health Promotion, 7(110), Available at: https://www.ncbi.nlm.nih.gov/pmc/articles/P MC6149116/\#

Tadele, W., Debebe, F., Tadele, A., \& Tilahun, L. (2020). Assessment of knowledge and practice of nurses working in gynecology emergency room towards pregnancy induced hypertension in selected government public hospitals found in Addis Ababa, Ethiopia.

Thilaganathan, B., \& Kalafat, E. (2019). Cardiovascular system in preeclampsia and beyond. Hypertension, 73(3), 522-531.
Upton, P, Scurlock-Evans, L, Williamson, K, Rouse, J, and Upton, D. (2015). The evidence- based practice profiles of academic and clinical staff involved in pre-registration nursing students' education: A cross sectional survey of US and UK staff. Nurse education today, 35(1): 80-85.

Verloo, H., Desmedt, M., and Morin, D., (2017). Beliefs and implementation of evidence-based practice among nurses and allied healthcare providers in the Valais hospital, Switzerland. Journal of evaluation in clinical practice. 23(1): 139-148.

Wu, Y., Brettle, A., Zhou, C., Ou, J., Wang, Y., \& Wang, S. (2018). Do educational interventions aimed at nurses to support the implementation of evidence-based practice improve patient outcomes? A systematic review. Nurse education today, 70, 109-114.

Zhran, F., R Aboshabana, K., \& M Emam, A. (2018). Nurses' practical skills provided for mother With Toxemia of Pregnancy. Egyptian Journal of Health Care, 9(1):25-37. 
تقييم معرفة وأداء الممرضات تجاه استخدام الممارسات القائمة على الأدلة للسيدات التي تعاني من تسمم الحمل دعاء السباعى سليمان - سامية عبد الحكيم عبودـ سميه عودة عبد المنعم ـ فاطمة كمال علي

تسمم الحمل هو اضطر اب تدريجي متعدد الأنظمة يؤثر على ما يصل إلى 0_^٪ من جميع حالات الحمل وهو جزء من طيف اضطر ابات ارتفاع ضغط الدم أثناء الحمل. لذلك هدفت هذه الدراسة إلى تقييم تطبيق الممارسة القائمة على الأدلة للسيدات التي تعانى من تسمم الحمل وقد أجريت الدراسة في قسم النسا و التوليد في مستشفى بنها الجامعى على (• (7) ممرضة. حيث كثفت النتائج عن ان هناك علاقة ذو دلالة إحصائية عالية بين المعلومات والأداء الكلي بعد البرنامج وهذا يعني أنه عندما تتحسن المعلومات يتحسن الأداء. علاوة على ذلك، كان هناك علاقة إيجابي ذات دلالة إحصائية بين الممارسات الكلية و المعرفة الكلية حول الممارسات القائمة على ليى الأدلة والمعرفة الكلية بتسمم الحمل. كما توجد علاقه إيجابي ذو دلالة إحصائية بين المعرفة الكلية حول الممارسات القائمة على الأدلة والمعرفة الكلية حول تسمم الحمل. كما أوصت الدر اسة بتطوير برامج تعليمية مستمرة للممرضات العاملات في قسم أمر اض النساء والتوليد لتعزيز معارفهن وممارساتهن فيما يتعلق بالر عاية مع تسمم الحمل و تحسين وعي الممرضات فيما يتعلق بـالممارسات المبنيه على الدلائل من خلال إثر اكهم في البر امج التعليمية لتشجيعهم على الاستفادة من الممارسات المبنيه على الدلائل في الرعاية اليومية للمرضى. 